\title{
Research Paper Scaling scan for sustainable and intensified agricultural production in Andhra Pradesh
}

\author{
V. Rajendra Prasad, S. Govinda Rao and A.V. Ramana
}

See end of the paper for authors' affiliations

Correspondence to :

V. Rajendra Prasad Agricultural College, ANGRAU, Naira (A.P.)

India

Email: pasadv2007@gmail. com

Paper History :

Received : 23.06.2020;

Revised : 15.07 .2020

Accepted : 17.08 .2020
ABSTRACT : In the recent times the number of farm holdings in Andhra Pradesh has increased amidst the decrease in net sown area resulting in reduction of average holding size from 1.06 ha to 0.94 ha. The organization of the already existing unemployed along with the returned migrant labour into cultivation co-operatives or farmer producer organizations, provision of training in production of agricultural and allied agricultural products, linking these activities with already existing government programmes and schemes could be the action plan to achieve sustainable and comprehensive food and nutritional security in addition to create additional employment opportunities in the rural areas. The scaling scan, a tool developed by PPP Lab and the International maize and wheat improvement center (CIMMYT) in 2017 was used to identify the critical areas that need attention for sustained and intensified agricultural production in Andhra Pradesh. The results revealed that value chain, finance, collaboration, leader ship and management are the scaling ingredients that scored less than three requiring overcoming several challenges in the above areas to reach the ambition of sustainable and intensified agricultural production in the state of Andhra Pradesh.

KEY WORDS : Scaling up, Sustainable intensification, Doubling of farmers income

JEL CODES O13, O15, O17

How To Cite This Paper : Prasad, V. Rajendra, Rao, S. Govinda and Ramana, A.V. (2020). Scaling scan for sustainable and intensified agricultural production in Andhra Pradesh. Internat. Res. J. Agric. Eco. \& Stat., 11 (2) : 191-197, DOI : 10.15740/HAS/IRJAES/11.2/191-197. Copyright@2020:Hind Agri-Horticultural Society. 